\title{
Variations of Strength, Resistivity and Thermal Parameters of Clay after High Temperature Treatment
}

\author{
Qiang SUN, Weiqiang ZHANG, Yuliang ZHANG, and Lining YANG \\ School of Resources and Geosciences, China University of Mining and Technology, \\ Xuzhou, Jiangsu Province, P.R. China \\ e-mails: zhangweiqiang1204@163.com (corresponding author), \\ sunqiang04@126.com
}

\begin{abstract}
This paper reports the variations of strength, resistivity and thermal parameters of clay after high-temperature heating. Experiments were carried out to test the physical properties of clay heated at temperatures ranging from room temperature to $800^{\circ} \mathrm{C}$ in a furnace. The experiment results show that below $400^{\circ} \mathrm{C}$ the uniaxial compressive strength and resistivity change very little. However, above $400^{\circ} \mathrm{C}$, both increase rapidly. At a temperature under $400^{\circ} \mathrm{C}$, the thermal conductivity and specific heat capacity decrease significantly. The thermogravimetric analysis (TG) and differential scanning calorimeter (DSC) test indicate that a series of changes occur in kaolinite at temperatures from 400 to $600^{\circ} \mathrm{C}$, which is considered the primary cause of the variation of physical and mechanical properties of clay under high temperatures.
\end{abstract}

Key words: high temperature, clay, strength, resistivity, thermal parameters.

\section{INTRODUCTION}

Clay is a common material, with broad applications in geomechanical engineering. Under the influence of high temperature, the mineral composition

Ownership: Institute of Geophysics, Polish Academy of Sciences;

(C) 2016 Sun et al. This is an open access article distributed under the Creative Commons Attribution-NonCommercial-NoDerivs license,

http://creativecommons.org/licenses/by-nc-nd/3.0/. 
and microstructure of clay change significantly (Sato et al. 1992, Aparicio and Galan 1999, Wu and Zhou 2008, Zhu et al. 2008). Meanwhile, various physical and mechanical properties are changed in the clay matrix. After being cooled down to room temperature, these thermally-induced variations are to some extent irreversible. Hence, the macroscopic physical and mechanical properties of clay depend on the temperature history, especially the maximum temperature that they were exposed to. Knowledge on the variation of the mechanical and physical properties of clay which are affected by temperature is important to understand and simulate many processes in various engineering projects, such as nuclear water storage (O'Flaherty and Gray 1974, Dixon et al. 1985, Radhokrishra and Chan 1989, Witherspoon 2001, AbuelNaga et al. 2009, Sundberg et al. 2009, Gens et al. 2010, Dupray et al. 2013), material modification (Sato et al. 1992, Zhang and Yuan 1993, Li et al. 2012), pollution controlling (Zheng et al. 2010, Sánchez et al. 2011), oil or gas industry (Cai 2003).

Numerous studies have shown that some properties of clay or claystone are correlated with thermal damage, such as mass, mechanical strength (e.g., compressive strength), Poisson's ratio, elastic modulus (Laloui and Cekerevac 2003, Zhang 2012, Tian et al. 2014, Mao et al. 2015), porosity, permeability (Ślizowski et al. 2003, Nelskamp et al. 2008, Melenevsky et al. 2009, Peltonen et al. 2009), thermal parameters (Monfared et al. 2011), chemical and mineral composition (Sun et al. 2015a), and wave velocity (Zhang 2012).

Therefore, the research on the thermo-physical-mechanical of clay is extremely meaningful on a wide range. In this paper, the variations of uniaxial compressive strength, resistivity and thermal parameters are analyzed after high-temperature heating.

\section{EXPERIMENTAL TESTS}

Clay samples used in these experiments are tan-eluvial soils collected from farmland in Xuzhou, Jiangsu Province. As shown in Fig. 1, the main composition was quartz and kaolinite.

The clay samples were first dried in a high temperature drying oven (keeps 2 hours under the temperature of $105^{\circ} \mathrm{C}$ ), then ground into powder and screened by a $1-\mathrm{mm}$ sieve to remove the impurities. The screened clay was shaped into cylindrical specimens of $\Phi 60 \times 70 \mathrm{~mm}$ by adding a small amount of water with a compaction device. The average of moisture content and density of the cylindrical specimens were $5 \%$ and $2.11 \mathrm{~g} / \mathrm{cm}^{3}$, respectively. Finally, the samples experienced the several steps of heat treatment by an MTS652.02 high-temperature furnace. The temperature was set into fourteen levels $(25,60,100,150,200,250,300,350,400,450,500,600$, 700 , and $800^{\circ} \mathrm{C}$ ), with four samples as a set. The heating process was com- 


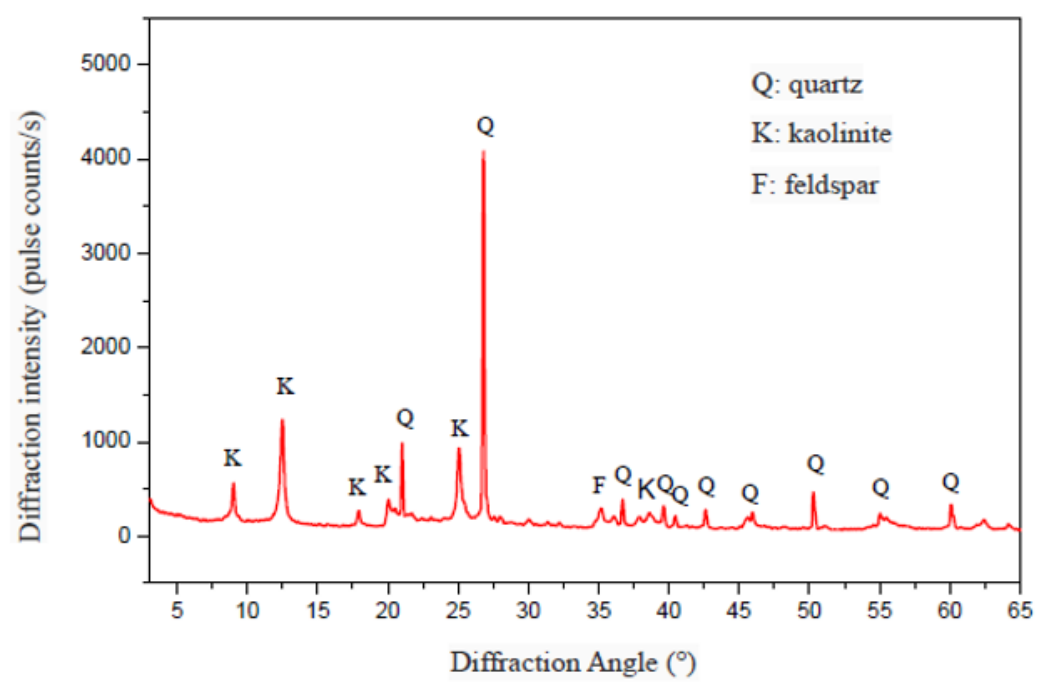

Fig. 1. XRD spectrum of a clay sample.

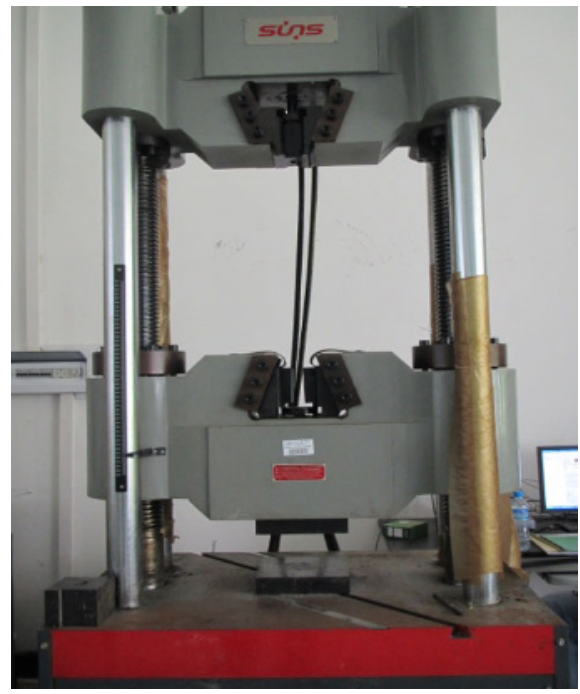

(a)

(b)

Fig. 2. The testing machine and resistivity detector: (a) loading apparatus, and (b) digital electrical instrument (SYSCAL-R2).

posed of three stages: (1) clay specimens were heated in the high-temperature furnace at the heating rate $30^{\circ} \mathrm{C} / \mathrm{min}$ until reaching the targeted temperature; (2) the targeted temperature was kept for $3 \mathrm{~min}$ to ensure that the inside of the samples was heated evenly; (3) the furnace was cooled down to room 
temperature by cutting off the power of furnace. The strength, resistivity, and thermal parameters of the specimens were tested before and after heating. The strength was tested with an electro-hydraulic servo-controlled testing machine (EHC-3000, produced by Sansi Instruments Co. Ltd. of Zhuhai, China, shown in Fig. 2a) at the loading speed of $0.5 \mathrm{kN} / \mathrm{s}$. The load was measured by an oil pressure sensor connected to the hydraulic pressure cylinder, and a cylindrical capacitor displacement sensor fixed to the upper plate was used to measure the displacement of clay samples in the test. The electrical resistivity was measured with a digital electrical instrument (SYSCAL-R2, produced by IRIS Instrument Co. Ltd, France, shown in Fig. 2b), and the information on thermal parameters was simultaneously collected by a TPS test machine produced by Hot Disk Equipment Co. Ltd. In addition, the TG curve (thermogravimetric analysis) of clay specimen

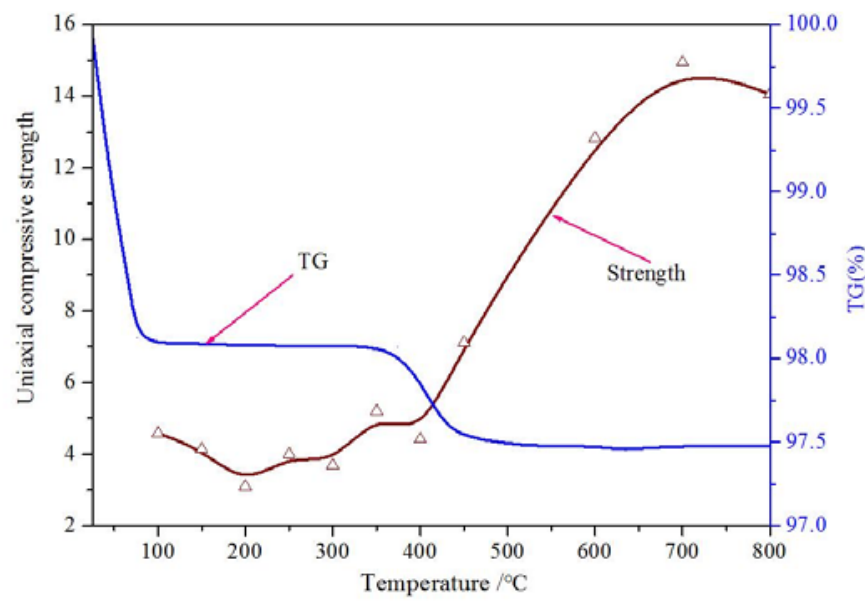

(a)

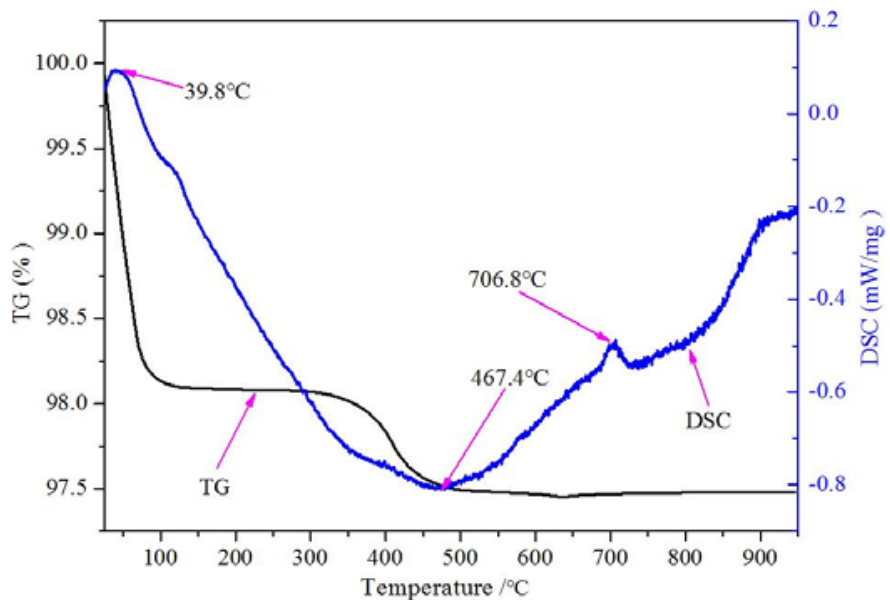

(b)

Fig. 3. Variation of uniaxial compressive strength, TG and DSC, after heating at different tempera-tures: (a) curve of compressive strength, and (b) curve of DSCTG. 
(shown in Fig. 3) was tested with a synchronous comprehensive thermal analyzer (type STA409C) produced by NETZSCH Co. Ltd., and in this test, the heating rate was set as $5 \mathrm{k} / \mathrm{min}$ and the gas flow rate was $100 \mathrm{~mL} / \mathrm{min}$.

\section{THE TEST RESULT ANALYSIS}

\subsection{Variation of uniaxial compressive strength}

The variation of uniaxial compressive strength with temperature is shown in Fig. 3. Two stages of variation can be identified: (i) Below $400^{\circ} \mathrm{C}$, the strength changes subtly with the increase of temperature (the strength is around $4 \mathrm{MPa}$ ); (ii) When temperatures are higher than $400^{\circ} \mathrm{C}$, the strength drastically increases with temperature. Combining this with the TG and DSC (differential scanning calorimeter) measurement curves shown in Fig. 4 (Zhu et al. 2008) and Fig. 5 (Wu and Zhou 2008), it can be deduced that when the temperature is higher than $400^{\circ} \mathrm{C}$, the temperature effect is mainly caused by the alteration of mineral content. From differential thermal analysis (DTA) of clay (as shown by Figs. 4 and 5), the dehydroxylation reaction of clay is obviously verified at the range from 400 to $650^{\circ} \mathrm{C}$. Therefore, in the heating process, kaolinite dehydroxylation yielding metakalinite occurs in the 400$650^{\circ} \mathrm{C}$ range (De Aza et al. 2014), as shown by the equations:

$$
\begin{gathered}
\mathrm{Al}_{2} \mathrm{O}_{3} \bullet 2 \mathrm{SiO}_{2} \bullet 2 \mathrm{H}_{2} \mathrm{O} \rightarrow \mathrm{Al}_{2} \mathrm{O}_{3} \bullet 2 \mathrm{SiO}_{2} \bullet \frac{1}{2} \mathrm{H}_{2} \mathrm{O}+\frac{3}{2} \mathrm{H}_{2} \mathrm{O} \\
\mathrm{Al}_{2} \mathrm{O}_{3} \bullet 2 \mathrm{SiO}_{2} \bullet \frac{1}{2} \mathrm{H}_{2} \mathrm{O} \rightarrow \mathrm{Al}_{2} \mathrm{O}_{3} \bullet 2 \mathrm{SiO}_{2}+\frac{1}{2} \mathrm{H}_{2} \mathrm{O}
\end{gathered}
$$

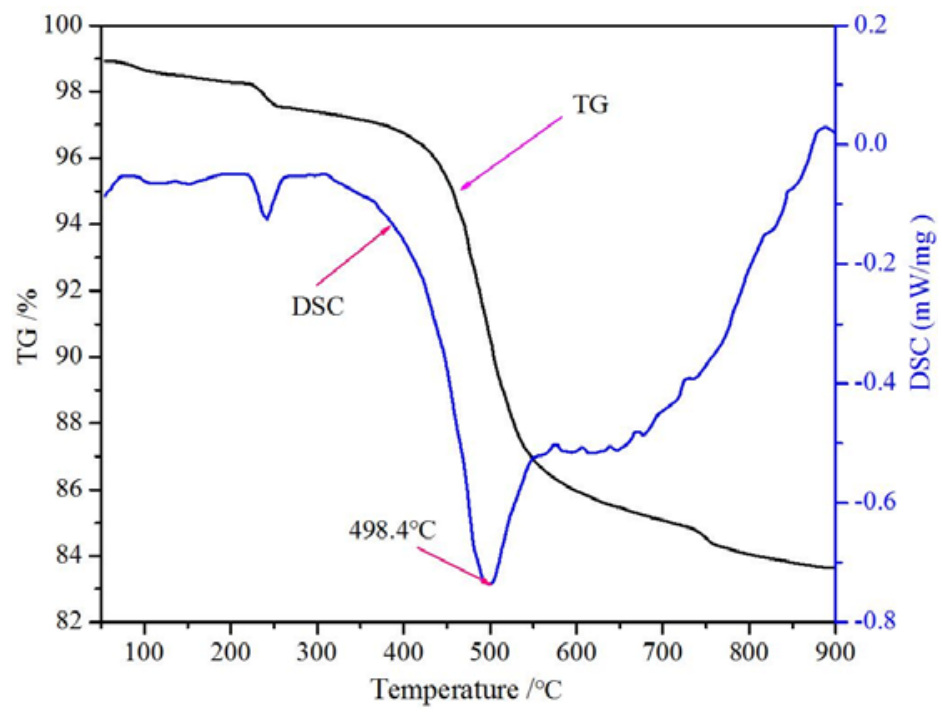

Fig. 4. DSC-TG diagram of Suzhou kaolinite (Zhu et al. 2008). 


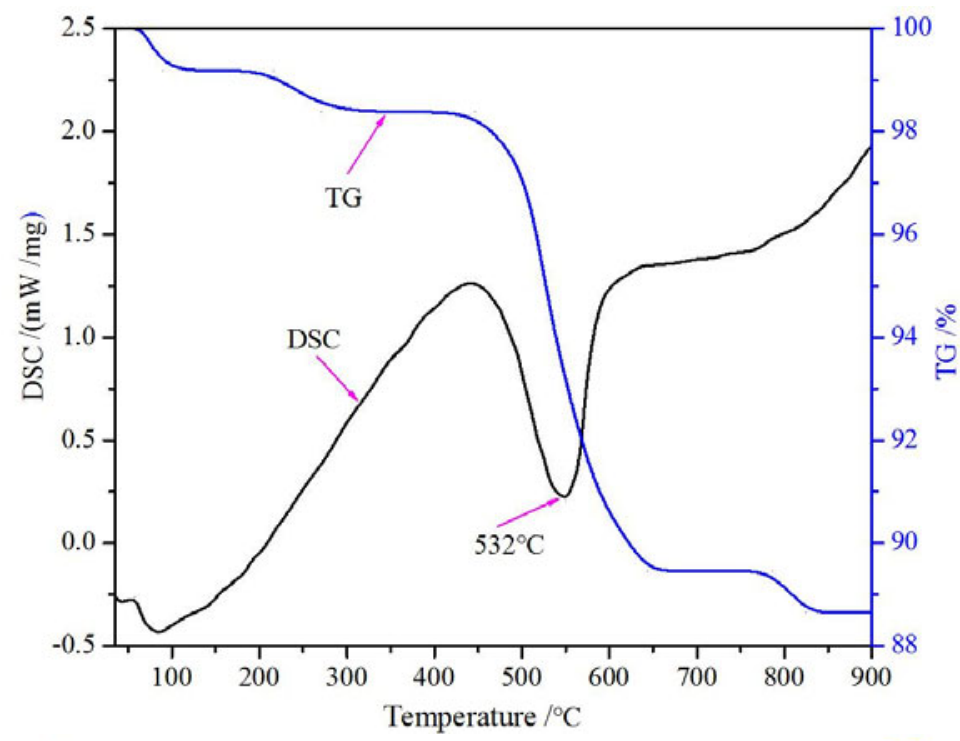

(a)

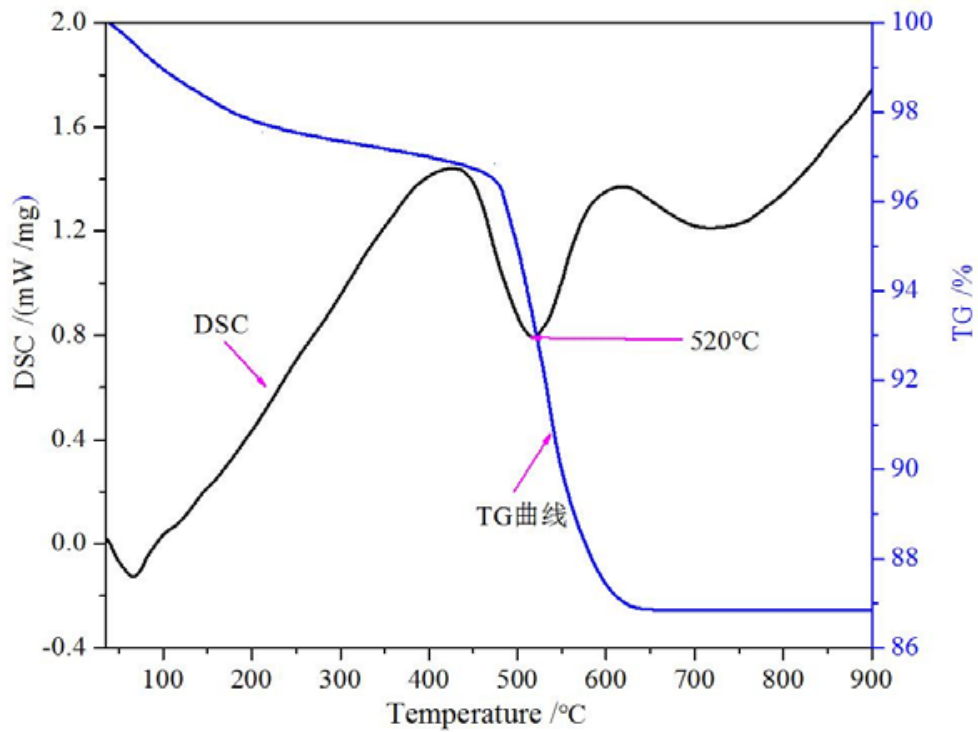

(b)

Fig. 5. DSC-TG diagram of kaolinite (Wu and Zhou 2008): (a) Tanwu kaolinite, and (b) Huling kaolinite.

In the heating process, kaolinite loses some hydroxyl (-OH) and the bond between particles is improved (Belloto et al. 1995, Lee et al. 1999). As a result, the improved cohesion between particles causes the increase of uniaxial compressive strength with temperature. 


\subsection{Variation of resistivity}

The principle of resistivity measurement is shown in Fig. 6: powering both ends of the rock sample and then, using the measuring electrodes at the upper and lower ends, we observe the potential difference between $\mathrm{MN}$ when the electrical current passes through the rock sample, so the resistivity can be calculated with the following Eq. 3. As the clay resistivity is relatively large, the intensity of current is too small to be measured directly. It is obtained indirectly by measuring the voltages at both ends of a $1 \mathrm{k} \Omega$ standard resistor in the power supply circuit with the switch K (Fig. 6).

$$
\rho=K \frac{\Delta U_{\mathrm{MN}}}{I} ; \quad K=A / L,
$$

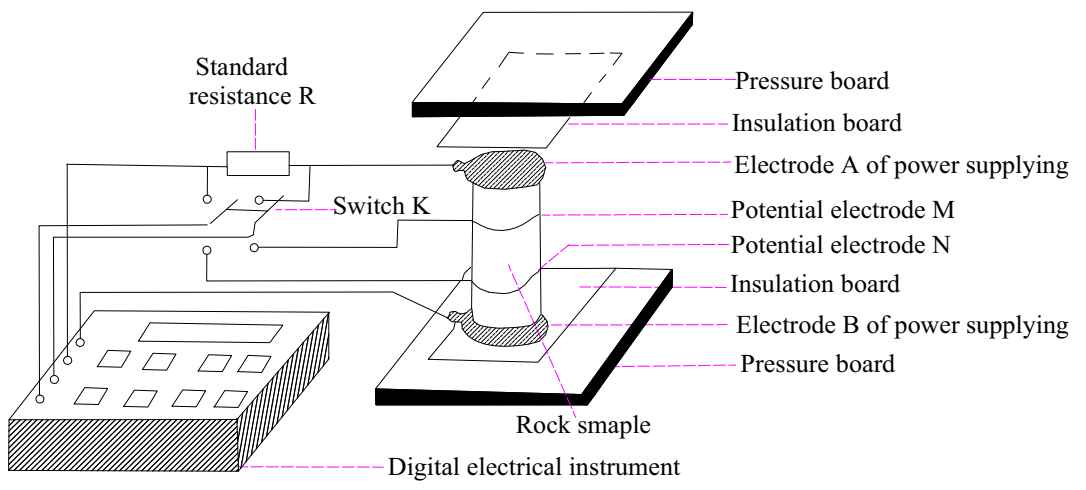

Fig. 6. Schematic diagram of the experimental system for stress and electrical resistance of clay under uniaxial compression (Sun et al. 2015b).

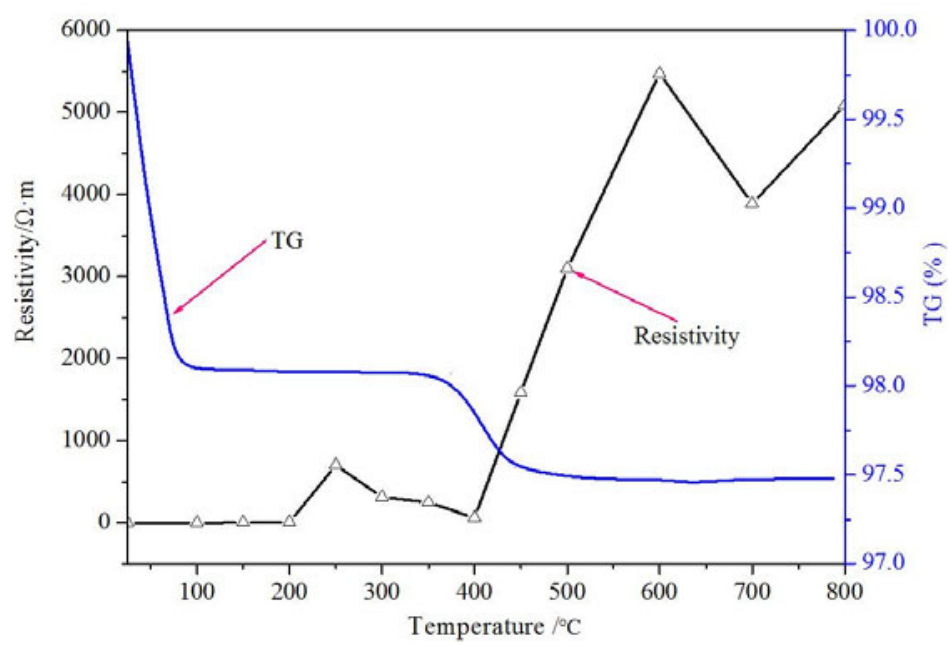

Fig. 7. Variation of specific resistivity at different temperatures. 


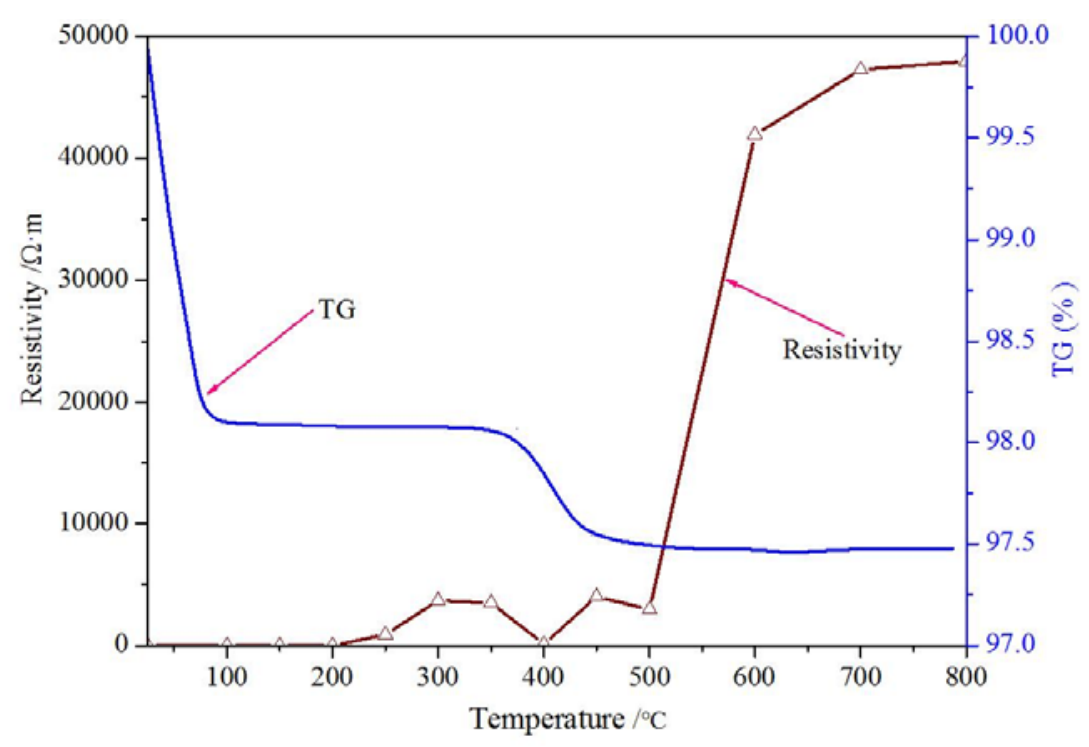

Fig. 8. Variation of resistivity (at the peak strength) at different temperatures.

where $K$ is a coefficient determined by device, $A$ is the cross-sectional area of rock sample; $L$ is the distance between $\mathrm{MN} ; \Delta U_{\mathrm{MN}}$ is the potential difference between $\mathrm{MN}$; and $I$ is current.

The variation of resistivity with temperature is shown in Figs. 7 and 8. Below $400^{\circ} \mathrm{C}$, the resistivity changes very little with the increase of temperature. When the temperature is higher than $400^{\circ} \mathrm{C}$, the resistivity quickly increases with temperature. This pattern of variation suggests that when the temperature is higher than $400^{\circ} \mathrm{C}$, the varied thermal effect results from the changing mineral content of the sample (shown by Eqs. 1 and 2).

\subsection{Variation of thermal parameters}

After high-temperature heating, the thermal conductivity, specific heat capacity and thermal diffusivity of clay specimens change significantly (as shown in Figs. 9-11) in the temperature range of $20-800^{\circ} \mathrm{C}$. From 25 to $400^{\circ} \mathrm{C}$, conductivity decreases rapidly with temperature, which is mainly due to growing numbers of pores. Above $400^{\circ} \mathrm{C}$, the thermal conductivity and specific heat capacity decrease a little bit. However, the thermal diffusivity presents a certain fluctuation, but the variation level is not apparent compared to thermal conductivity and specific heat capacity. It should be pointed out that the properties of clay in this phase (above $400^{\circ} \mathrm{C}$ ) are close to rock. The variation of thermal conductivity with temperature is shown by Fig. 9 and the following Eq. 4 


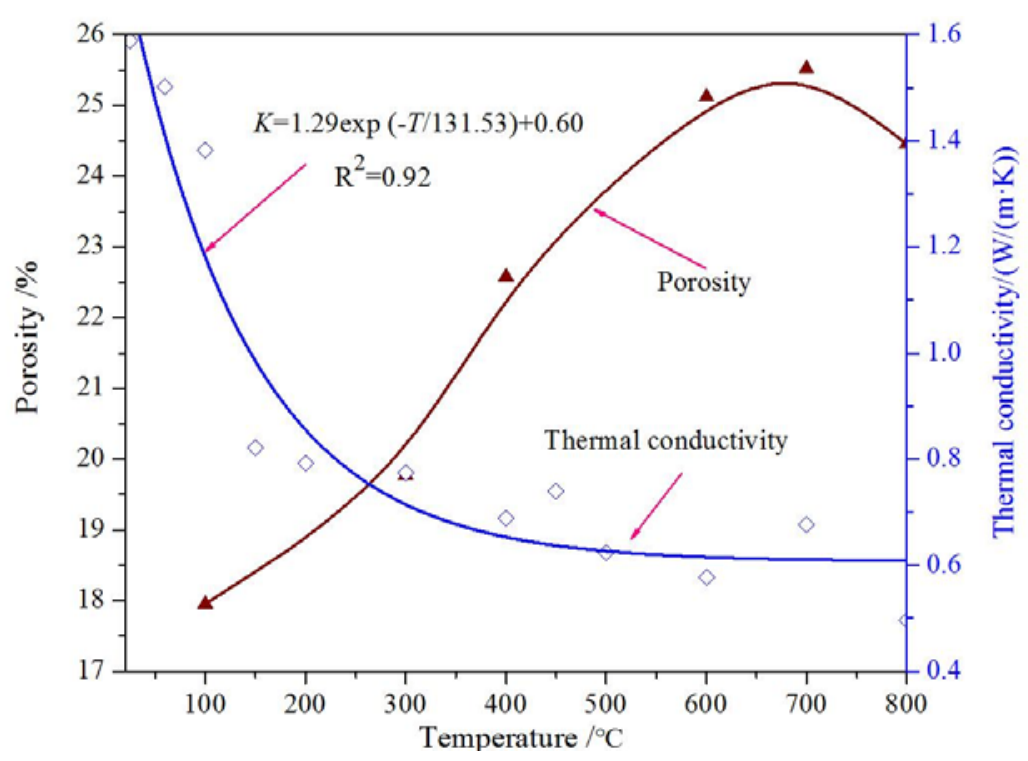

Fig. 9. Variations of thermal conductivity and porosity at different temperatures.

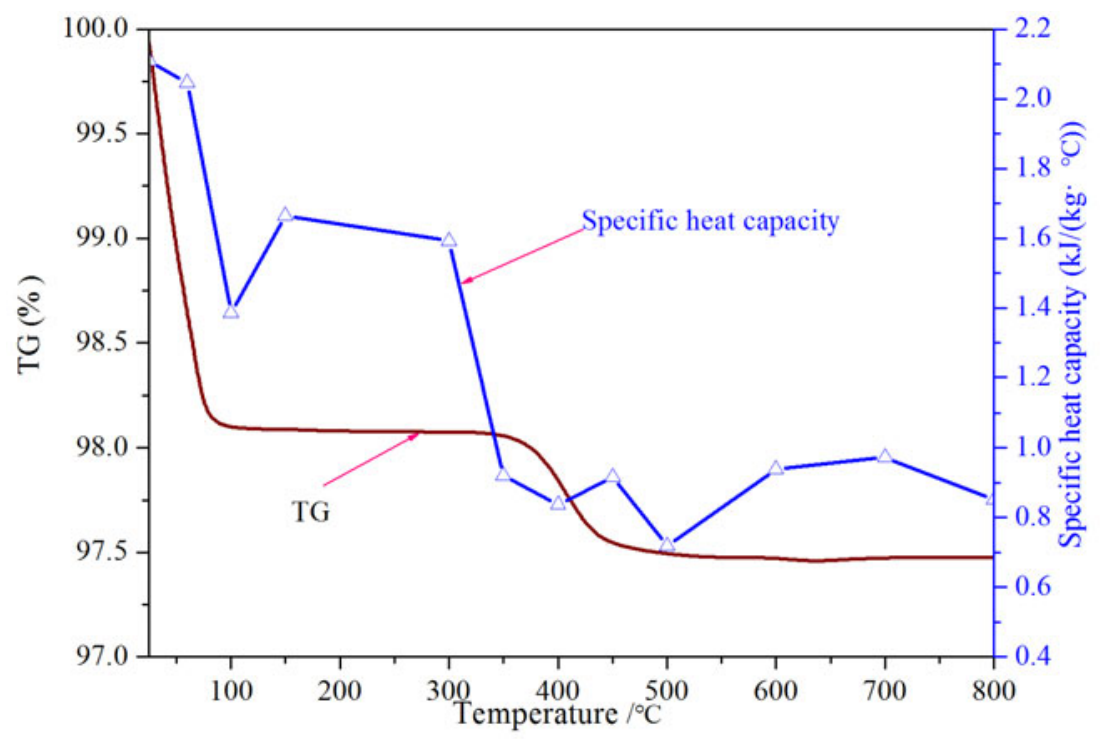

Fig. 10. Variations of specific heat capacity and TG at different temperatures.

$$
K=1.29 \exp \left(-\frac{T}{131.53}\right)+0.60 ; \quad R^{2}=0.92,
$$

where $T$ is temperature, and $K$ is thermal conductivity. 


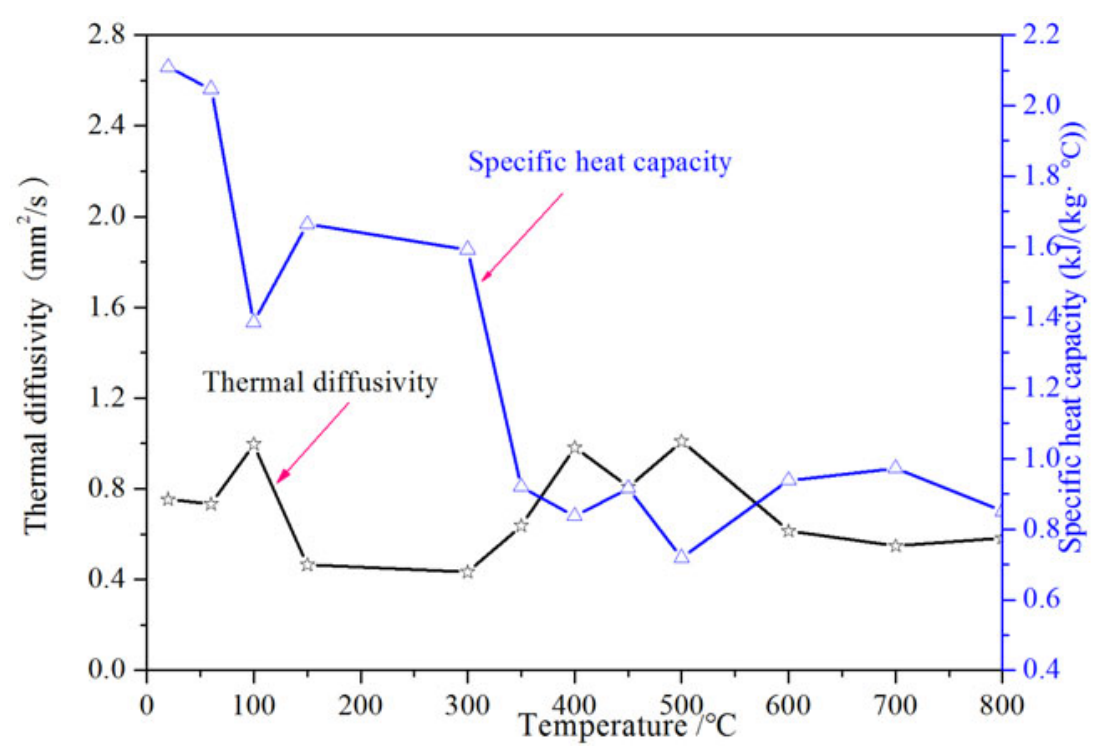

Fig. 11. Variations of specific heat capacity and thermal diffusivity at different temperatures.

\section{DISCUSSION}

The main mechanism of changes in physical properties of clay after thermal treatment is the damage of clay structure caused by thermal reactions. Generally speaking, clay is composed of different minerals. In the heating progress, there is a series of chemical reactions. Adsorbed and interlayer water can evaporate (i.e., desorption) at the temperature range of $100-250^{\circ} \mathrm{C}$, and the structural water is lost when the treatment temperature is higher than $300^{\circ} \mathrm{C}$. When the heating temperature is lower than the threshold value, the variation of clay is mainly due to the change of all kinds of water. The existence of water seriously affects the porosity. Another reason: in the progress of losing structural water, some minerals are decomposed and evaporated (for example, the dehydroxylation of clay minerals), which may cause the increase of pore and fracture.

Organic matter is comparatively enriched in muddy sediments (Hunt 1996). Above $300^{\circ} \mathrm{C}$, this organic matter begins to turn into char residue. The oxidation/decomposition reaction of organic matters is obviously evidenced in the range from $300^{\circ} \mathrm{C}$ (especially $400^{\circ} \mathrm{C}$ ) to $500^{\circ} \mathrm{C}$. Results of Fig. 12 show that the exothermal peak at $350^{\circ} \mathrm{C}$ is more strongly marked (Cai 2003, Cai et al. 2007), while the exothermal peak above $350^{\circ} \mathrm{C}$ disappeared. It indicates that organic matter is incorporated with clay minerals closely and stably. Therefore, oxidation/decomposition reaction of organic 


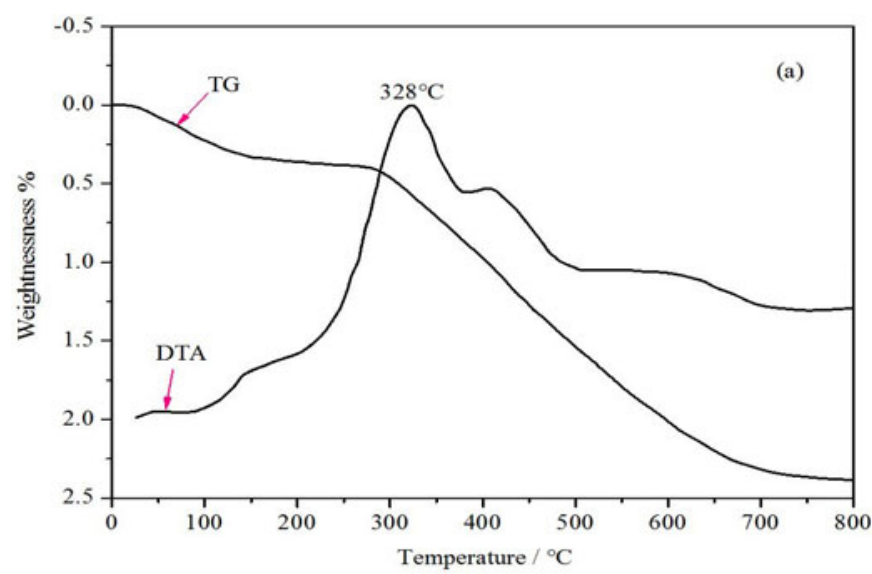

(a)

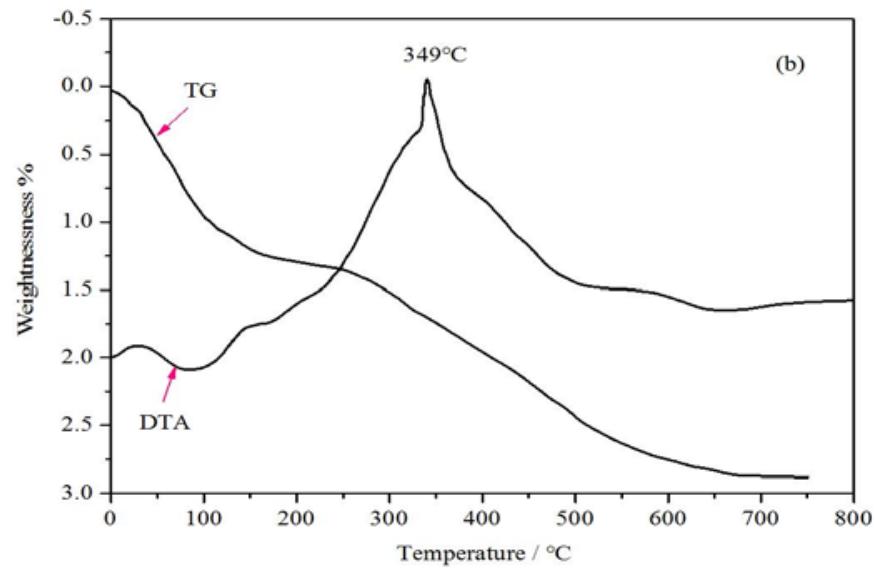

(b)

Fig. 12. The TG and DTA curves of clay samples No. 26 (a) and No. 3 (b) (Cai et al. 2007).

matters is obviously evidenced in the period ranging from 300 to $500^{\circ} \mathrm{C}$, which leads to decrease of mass and increase of porosity. When the heating temperature reached the critical value, some of the carbonate minerals (such as calcium carbonate, magnesium carbonate, magnesite, dolomite) starts to decompose and results in the decrease of elastic modulus, compressive strength, tensile strength, and fracture toughness. Moreover, when the treatment temperature is higher than $400^{\circ} \mathrm{C}$, the oxidation of organic matter is quickly increasing.

\section{CONCLUSION}

The study of characteristics of strength, resistivity, and thermal parameters of clay heated at different temperatures is reported in this paper. Based on the results, the following conclusions can be drawn: 
- Temperature has a significant impact on the physical and mechanical properties of clay;

- Between 100 and $400^{\circ} \mathrm{C}$, the uniaxial compressive strength and resistivity of clay change very little with temperature. Above $400^{\circ} \mathrm{C}$, the strength and resistivity rise rapidly. The variations of uniaxial compressive strength and resistivity are significantly affected by altered mineral clay composition between 400 and $600^{\circ} \mathrm{C}$;

- The thermal conductivity and specific heat capacity of clay specimens change significantly after treatment at high temperatures. From 20 to $400^{\circ} \mathrm{C}$, they decrease rapidly with temperature. Above $400^{\circ} \mathrm{C}$, both thermal conductivity and specific heat capacity decrease slightly.

Finally, it is worth mentioning that these characteristics of variation of clay properties were observed in laboratory tests. Permeability and ultrasonic measurement will also be included in future work.

Acknowledgments. This research was supported by "the Fundamental Research Funds for the Central Universities" (No. 2015XKMS033) and the Priority Academic Program Development of Jiangsu Higher Education Institutions.

\section{References}

Abuel-Naga, H.M., D.T. Bergado, A. Bouazza, and M.J. Pender (2009), Thermal conductivity of soft Bangkok clay form laboratory and field measurements, Eng. Geol. 105, 3-4, 211-219, DOI: 10.1016/j.enggeo.2009.02.008.

Aparicio, P., and E. Galan (1999), Mineralogical interference on kaolinite crystallinity index measurements, Clay. Clay Miner. 47, 1, 12-27, DOI: 10.1346/ CCMN.1999.0470102.

Belloto, M., A. Gualtieri, G. Artioli, and S.-M. Clark (1995), Kinetic study of the kaolinite-mullite reaction sequence. Part II: Mullite formation, Phys. Chem. Minerals 22, 4, 215-222, DOI: 10.1007/BF00202254.

Cai, J.G. (2003), Oregano-clay complexes in muddy sediments and mudstones, Ph.D. Thesis, Tongji University, Shanghai (in Chinese).

Cai, J.G., Y.J. Bao, S.Y. Yang, X.X. Wang, D.D. Fan, J.L. Xu, and A.P. Wang (2007), Research on preservation and enrichment mechanisms of organic matter in muddy sediment and mudstone, Sci. China D 50, 5, 765-775, DOI: $10.1007 / \mathrm{s} 11430-007-0005-0$.

De Aza, A.H., X. Turrillas, M.A. Rodriguez, T. Duran, and P. Pena (2014), Timeresolved powder neutron diffraction study of the phase transformation se- 
quence of kaolinite to mullite, J. Eur. Ceram. Soc. 34, 5, 1409-1421, DOI: 10.1016/j.jeurceramsoc.2013.10.034.

Dixon, D.A., M.N. Gray, and A.W. Thomas (1985), A study of the compaction properties of potential clay-sand buffer mixtures for use in nuclear fuel waste disposal, Eng. Geol. 21, 3-4, 247-255, DOI: 10.1016/0013-7952(85) 90015-8.

Dupray, F., C. Li, and L. Laloui (2013), Thermal conductivity of soft Bangkok clay form laboratory and field measurements, Eng. Geol. 163, 113-121, DOI: 10.1016/j.enggeo.2013.05.019.

Gens, A., L. do Guimarães, S. Olivella, and M. Sánchez (2010), Modelling thermohydro-mechano-chemical interactions for nuclear waste disposal, J. Rock Mech. Geotech. Eng. 2, 2, 97-102, DOI: 10.3724/SP.J.1235.2010.00097.

Hunt, J.M. (1996), Petroleum Geochemistry and Geology, 2nd ed., W.H. Freeman and Co., New York, 100 pp.

Laloui, L., and C. Cekerevac (2003), Thermo-plasticity of clays an isotropic yield mechanism, Comp. Geotech. 30, 8, 649-660, DOI: 10.1016/j.compgeo. 2003.09.001.

Lee, S., Y.J. Kim, and H.S. Moon (1999), Phase transformation sequence from kaolinite to mullite investigated by an energy-filtering transmission electron microscope, J. Am. Ceram. Soc. 82, 10, 2841-2848, DOI: 10.1111/j.11512916.1999.tb02165.x.

Li, Y., Q.C. Yu, B. Yang, and Y. Dai (2012), Characterization of vacuum thermal decomposed kaolin vacuum, Chin. J. Vacuum Sci. Tech. 32, 599-604 (in Chinese).

Mao, R.R., X.B. Mao, L.Y. Zhang, and R.X. Liu (2015), Effect of loading rates on the characteristics of thermal damage for mudstone under different temperatures, Int. J. Min. Sci. Technol. 25, 5, 797-801, DOI: 10.1016/j.ijmst. 2015.07.015

Melenevsky, V.N., A.E. Kontorovich, and W.L. Huang, A.I. Larichev, and T.A. Bul'bak (2009), Hydrothermal pyrolysis of organic matter in Riphean mudstone, Geochem. Int. 47, 5, 476-484, DOI: 10.1134/ S0016702909050048.

Monfared, M., J. Sulem, P. Delage, and M. Mohajerani (2011), A laboratory investigation on thermal properties of the opalinus claystone, Rock Mech. Rock Eng. 97, 735-747, DOI: 10.1007/s00603-0110-0171-4.

Nelskamp, S., P. David, and R. Littke (2008), A comparison of burial, maturity and temperature histories of selected wells from sedimentary basins in the Netherlands, Int. J. Earth Sci. 97, 5, 931-953, DOI: 10:1007/s00531-0070229-4.

O'Flaherty, C.A., and M.N. Gray (1974), The influence of alkali compounds on the compaction and early strength properties of lime-soil mixtures, Austral. Road Res. 5, 5, 4-15. 
Peltonen, C., Ø. Marcussen, Bjørlykke, and J. Jahren (2009), Clay mineral diagenesis and quartz cementation in mudstones: The effects of smectite to illite reaction on rock properties, Mar. Petrol. Geol. 26, 6, 887-898, DOI: 10.1016/ j.marpelgeo.2008.01.021.

Radhokrishra, H.S., and H.T. Chan (1989), Thermal and physical properties of candidate buffer-backfill material for a nuclear fuel waste disposal vault, Can. Geotech. 26, 6, 629-639, DOI: 10.1016/0148-9062(90)92830-8.

Sánchez, M., A. Shastri, and A. Gens (2011), Transient behavior of a clay barrier subjected to high temperature changes, Geo-Frontiers 2011, 4156-4165, DOI: $10.1061 / 41165(397) 425$.

Sato, T., T. Watanable, and Otsuka (1992), Effects of layer charge location and energy change on expansion properties of dioctahedral smectite, Clay. Clay Miner. 40, 1, 103-113, DOI: 10.1346/CCMN.1992.0400111.

Ślizowski, K., J. Janeczek, and K. Przewłocki (2003), Suitability of salt-mudstones as a host rock in salt domes for radioactive-waste storage, Appl. Energ. 75, 1-2, 119-128, DOI: 10.1016/S0140-6701(04)91754-7.

Sun, L.N., Z.N. Zhang, Y.D. Wu, L. Su, Y.Q. Xia, Z.D. Gao, Y.W. Zheng, and Z.X. Wang (2015a), Effect of temperature and pressure on hydrocarbon yield of source rock HTHP simulation experiment in semi-open system, Nat. Gas. Geosci. 26, 1, 118-127, DOI: 10.11764/j.issn.1672-1926.2015.01. 0118 (in Chinese).

Sun, Q., S.Y. Zhu, and L. Xue (2015b), Electrical resistivity variation in uniaxial rock compression, Arab. J. Geosci. 8, 4, 1869-1880, DOI: 10.1007/s12517014-1381-3.

Sundberg, J., P.E. Back, R. Christiansson, H. Hökmark, M. Ländell, and J. Wrafter (2009), Modeling of thermal rock mass properties at the potential sites of a Swedish nuclear waste repository, Int. J. Rock Mech. Min. Sci. 46, 6, 10421054, DOI: 10.1016/j.ijrmms.2009.02.004.

Tian, H., M. Ziegler, and T. Kempka (2014), Physical and mechanical behavior of claystone exposed to temperatures up to $1000^{\circ} \mathrm{C}$, Int. J. Rock Mech. Min. Sci. 70, 144-153, DOI: 10.1016/j.ijrmms.2014.04.014.

Witherspoon, P.A. (2001), Geological Challenges in Radioactive Waste Isolation, Third Word Rev., California, USA.

Wu, J.G., and H.W. Zhou (2008), Dynamic experimental research on phase transformation of Kaoliniteiteunder high temperature within microzone, Nonmetallic. Min. 31, 6, 10-13, DOI: 10.1016/j.clay.2013.07.017 (in Chinese).

Zhang, L.Y. (2012), Research on damage evolution and fracture mechanisms of mudstone under high temperature, Ph.D. Thesis, China. Univ. Min. Tech., Xuzhou (in Chinese).

Zhang, Z.Q., and R.Z. Yuan (1993), Study on dchydroxylation process of Kaolinite and its structural change, Bull. Chin. Ceramic Soc. 14, 37-41 (in Chinese). 
Zheng, J.D., B.B. Chang, T.T. Chen, and J. Yin (2010), Study on the high temperature modification of attapulgite, Appl. Chem. Industry 39, 1835-1837 (in Chinese).

Zhu, H.J., X. Yao, and Z.H. Zhang (2008), Optimization of calcined temperature for Kaolinite activation, J. Build. Mater. 11, 621-625 (in Chinese).

Received 19 June 2015

Received in revised form 4 February 2016

Accepted 5 April 2016 